\title{
T Peak-T End Interval Alteration as Parameter of Successful Fibrinolysis in Patients with ST Segment Elevation Acute Myocardial Infarction
}

\author{
Windhi Dwijanarko*, Erika Maharani, Dyah Wulan Anggrahini \\ Department of Cardiology and Vascular Medicine Faculty of Medicine Universitas GadjahMada - Dr.Sardjito Hospital, \\ Yogyakarta, Indonesia \\ ${ }^{*}$ Corresponding author: \\ Windhi Dwijanarko, MD, - email: windhi.dwijanarko@yahoo.com \\ Department Cardiology and Vascular Medicine Faculty of Medicine Universitas Gadjah Mada - Dr. Sardjito Hospital, \\ Jalan Farmako Sekip Utara Yogyakarta, 55281, Indonesia,
}

Manuscript submitted:July 22, 2017; Revised and accepted for publication:September 24, 2017

\section{ABSTRACT}

Background: In STEMI patients, the duration of action potential dispersion occurs between normal and ischemic tissue due to the lengthening of the refractory period, causing transmural dispersion of repolarization, which could be detected with Tp-Te interval prolongation on the electrocardiogram (ECG). Benefits of fibrinolytic therapy in patients with STEMI has been demonstrated, with reduced mortality significantly and improve coronary patency in order to increase myocardial perfusion. The goal of this study was to determine Tp-Te interval alteration in STEMI patients before and after the fibrinolytic therapy between successful fibrinolysis compared to failed fibrinolysis.

Method: Cross-sectional study was conducted to collect ECG from medical records at Dr. Sardjito General Hospital in January-September 2016. STEMI patients with onset less than 12 hours whom reperfused with fibrinolytic therapy were registered. Tp-Te interval was measured before, soon after ( 0 minute), and 30 minutes after fibrinolysis with successful and failed results. The unpaired t-test analysis was used to compare Tp-Te interval alteration after fibrinolysis. Then, $\Delta T p$-Te cut-off value was determined to find sensitivity and specificity based on ROC.

Result: Among 84 patients enrolled in this study, 46 patients with successful fibrinolysis and 38 patients with failed fibrinolysis. Both of groups had Tp-Te interval prolongation before fibrinolysis, with mean value of $120.30 \pm 13.02 \mathrm{~ms}$ in successful fibrinolysis group and $118.57 \pm 15.24 \mathrm{~ms}$ in failed fibrinolysis group. In successful fibrinolysis group, Tp-Te interval reduced significantly with $\Delta \mathrm{Tp}$-Te value of $17.55 \pm 13.35 \mathrm{~ms}$ on 0 minute and $20.85 \pm 15.62 \mathrm{~ms}$ on 30 minutes after fibrinolysis, while in failed fibrinolysis group there was not a decrease of Tp-Te interval with $\Delta T p-T e$ value of $-0.77 \pm 11.00 \mathrm{~ms}$ on 0 minute $(p<0.001)$ and $-1.53 \pm 14.35 \mathrm{~ms}$ on 30 minutes after fibrinolysis $(p<0.001)$. Cut-off value $\Delta$ Tp-Te $20 \mathrm{~ms}$ had sensitivity $52.2 \%$ and specificity $94.7 \%$ based on ROC, with strong discriminator value of AUC (0.888).

Conclusion: There was a greater reduction of Tp-Te interval in STEMI patients with successful fibrinolysis compared to failed fibrinolysis, so it may be used as a alternative parameter of successful fibrinolysis.

Keywords: STEMI; Tp-Te interval; fibrinolysis

\section{INTISARI}

Latar Belakang: Pada pasien dengan STEMI, durasi dispersi potensial aksi terjadi antara jaringan normal dan iskemik karene pemanjangan periode refrekter, menyebabkan dispersi transmural dari repolarisasi. Hal ini bisa dideteksi dari pemanjangan interval Tp-Te pada elektro kardiogram (EKG). Kegunaan terapi fibrinolisis pada pasien dengan STEMI telah ditunjukkan pada pasien dengan STEMI dengan penurunan angka kematian secara signifikan dan perbaikan patensi koroner untuk meningkatkan perfusi miokard. Tujuan penelitian ini untuk menentukan perubahan interval Tp-Te pada pasien STEMI sebelum dan sesudah terapi fibrinolisis, membandingkan antara yang sukses dan yang gagal. 
Metode: Penelitian potong lintang dilakukan untuk mengumpulkan EKG dari rekam medis di RSUP Dr Sardjito antara Januari-September 2016. Pasien STEMI dengan awitan kurang dari 12 jam yang menjalani fibrinolisis didaftar dalam analisis. Interval Tp-Te diukur sebelum, segera setelah (menit 0) dan 30 menit setelah fibrinolisis, dengan hasil sukses dan gagal. Analisis uji T tak berpasangan digunakan untuk membandingkan perubahan interval Tp-Te setelah fibrinolisis. Nilai cut-off $\Delta \mathrm{Tp}$-Te digunakan untuk menentukan sensitivitas dan spesifisitas berdasarkan kurva ROC. Hasil: Sebanyak 84 pasien didaftarkan dalam penelitian ini, 46 pasien dengan fibrinolisis sukses dan 38 pasien dengan fibrinolisis gagal. Kedua kelompok mempunyai pemanjangan interval $\mathrm{Tp}$-Te sebelum fibrinolisis, dengan rerata 120,30 $\pm 13,02$ milidetik pada kelompok fibrinolisis sukses dan $118,57 \pm 15,24$ milidetik pada kelompok fibrinolisis gagal.Pada kelompok fibrinolisis sukses, interval Tp-Te menurun secara signifikan dengan nilai $\Delta \mathrm{Tp}-\mathrm{Te} 17,55 \pm 13,35$ milidetik pada menit 0 dan 20,85 $\pm 15,62$ milidetik pada menit 30 setelah fibrinolisis, sedangkan pada kelompok fibrinolisis gagal tidak terdapat penurunan interval Tp-Te dengan nilai $\Delta \mathrm{Tp}-\mathrm{Te}-0,77 \pm 11,00$ milidetik pada menit $0(p<0,001)$ dan $-1,53 \pm 14,35$ milidetik pada 30 menit setelah fibrinolisis $(p$ $<0,001$ ). Nilai cut-off $\Delta$ Tp-Te 20 milidetik mempunyai sensitivitas $52,2 \%$ dan spesifisitas $94,7 \%$ berdasarkan kurva ROC, dengan nilai diskriminator kuat AUC $(0,888)$.

Kesimpulan: Terdapat penurunan interval Tp-Te lebih besar pada pasien STEMI dengan fibrinolisis sukses dibandingkan pada yang fibrinolisis gagal, sehingga interval Tp-Te dapat digunakan sebagai alternatif parameter keberhasilan fibrinolisis.

\section{INTRODUCTION}

Coronary artery disease $(C A D)$ is still the number one cause of mortality worldwide, with more than 7 million deaths due to CAD each year, which represented $12.8 \%$ of all causes of death. ${ }^{1}$ ST elevation acute myocardial infarction (STEMI) is a clinical syndrome, which is a spectrum of acute coronary syndrome (ACS), which is defined by the characteristic symptoms of myocardial ischemia related with ST segment elevation in electrocardiography (ECG) and afterward followed with myocardial necrosis.

Myocardial ischemia causes metabolic changes and ion exchange. This cellular processes will lengthen repolarization and shorten the action potential in myocardium ischemic area. $^{2}$

Differences in the duration of action potentials between normal and ischemic tissue due to the lengthening of the refractory period raises electrophysiological inhomogenity in the ventricular myocardium and improves transmural dispersion of repolarization. This process may act as a predisposing factor reentry arrhythmias. This arrhythmia is the most common cause of death in STEMI patients. ${ }^{3,4}$
Several studies show a decrease in mortality due to STEMI, along with the increase use of reperfusion therapy, the availability of percutaneous coronary intervention $(\mathrm{PCl})$ facilities, modernantithrombotic therapy and secondary prevention. ${ }^{5}$ Benefits of fibrinolytic therapy in patients with STEMI has been demonstrated, with significant reduction of mortality by administration of fibrinolytic therapy. ${ }^{6}$ Traditional variables that had been used to assess response to fibrinolytic therapy was still less precision. ${ }^{7}$

Dispersion of repolarization increase can be detected by a peak interval prolongation Tpeak - Tend (Tp-Te) on 12 lead electrocardiogram examination. Tp-Te interval is a time interval measured from the top of the $T$ wave to the end of the T wave In some studies, Tp-Te interval is proposed as a marker of increased risk of ventricular arrhythmias in patients with various conditions, including acute myocardial infarction.8, 8,10 Another study said that STEMI patients who performed the reperfusion with primary $\mathrm{PCl}$, rescue $\mathrm{PCl}$ and successful fibrinolysis, duration of repolarization is significantlydecreased as assessed by Tp-Te. In addition, Tp-Te interval can be a response 
parameter and marker of successful reperfusion. ${ }^{11}$ However, until now there is no study evaluating the Tp-Te interval and the change in STEMI patients who performed fibrinolysis with successful and failed results and propose amendments Tp-Te interval as a parameter of successful fibrinolysis.

The aim of this study was to determine Tp-Te interval alteration in STEMI patients before and after the fibrinolytic therapy between successful fibrinolysis compared to failed fibrinolysis.

\section{METHODS}

This is an analytic observational study with cross sectional method on two unpaired groups. Data were obtained retrospectively to see Tp-Te interval change in STEMI patients who received fibrinolysis with successful and failed results. The study took place in the Medical Record Installation Dr. Sardjito General Hospital in January-September 2016 for collection of secondary data.

\section{Subjects}

Inclusion criteria in this study were STEMI patient at first time with onset within 12 hours and receive reperfusion therapy with fibrinolysis, aged 18-80 years, with complete data on the patient's medical record. While exclusion criteria of this research is atrial fibrillation, atrial flutter, ECG with LBBB, total AV block, pacing rhythm, or pre-excitation, chronic heart failure, valvular heart disease, congenital heart disease, electrolyte disturbances, drug history amiodarone and digitalis, duration QRS more than $12 \mathrm{~ms}$ in the ECG, and T-wave in the ECG difficult to assess.

\section{ECG Recording}

ECG recording done by using a standard 12 lead ECG with a speed of $25 \mathrm{~mm} / \mathrm{sec}$ and gain of $10 \mathrm{~mm} / \mathrm{mV}$ by medical or paramedical personnel in the emergency department of
Dr. Sardjito General Hospital accordance with the standard operating procedures of ECG collection. ECG data is used in STEMI patients with fibrinolysis action is ECG data when admission or pre- and post-fibrinolysis counted 90 minutes since the fibrinolysis started. ECG data is scanned in order to be processed digitally with a Canon brand scanner Canoscan Lide 110.

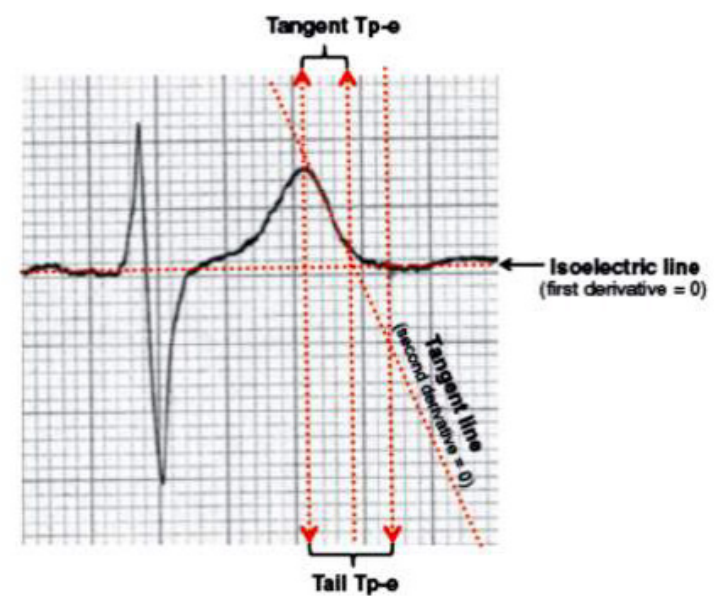

Figure 1. Measurement of Tp-Teinterval (source:Erikssen et al., 2012) ${ }^{12}$

\section{Tp-Te Interval Measurement}

Tp-Te measurements performed on precordial leads. Measurements were done using standard ECG at $\mathrm{V}_{5}, \mathrm{~V}_{4}$ and $\mathrm{V}_{6}$ lead. In previous study, $V_{5}$ lead is a measurement having high precision(Figure 1). If the calculation is not possible in $\mathrm{V}_{5}$, the alternative calculation of $\mathrm{Tp}$ Te interval in a sequence can be calculated from $\mathrm{V}_{4}$ and then $\mathrm{V}_{6} \cdot{ }^{13,14}$ In the case of the $\mathrm{T}$ wave disturbed by waves $U$, Te is defined as nadir between the $T$ wave with wave $U$. T wave with low voltage $<0.1 \mathrm{mV}$ is not analyzed. ${ }^{15}$

\section{Statistical Analysis}

The data obtained will be analyzed using the software SPSS for Windows version 18.0. The baseline characteristics are shown as mean or amount in figures and percentages. A comparative analysis was conducted between the 2 groups with paired $t$ test in each group 
(pre and post-fibrinolysis) and unpaired t test to compare between the two groups of fibrinolysis success and failure or test Mann-Whitney and Wilcoxon two numeric variables when the data is not normal to see whether there is a significant difference between the two variables with a proficiency level of significance value of $p<$ 0.05 . Analysis of confounding variables will be performed by multivariate analysis with multiple linear regression analysis. Further changes in the value, expressed in delta, is used to find the limit value using receiver operator characteristics (ROC) curves then prepared a sensitivityspecificity curve to help determine the sensitivity and specificity of the limit value.

\section{RESULT}

In this study there were 84 patients enrolled and met the inclusion and exclusion criteria. It was then divided into two following groups, successful fibrinolysis with 46 patients $(54.76 \%)$ and failed fibrinolysis in 38 patients $(45.24 \%)$. Of the subjects of this study, there were a total of 77 male patients and 7 (8.33\%) patients were female. The mean age at all subject was $56.63 \pm 10.023$ years. Average onset all the subjects were $4.36 \pm 2.143$ hours. Table 1 shows the baseline characteristics based on fibrinolysis results.

In this study, we obtained Tp-Te interval prolongation prior to the action of fibrinolysis in both groups of subjects, i.e. both in successful fibrinolysis group and failed fibrinolysis group, $120.30 \pm 13.02 \mathrm{~ms}$ and $118.57 \pm 15.24 \mathrm{~ms}$, respectively. Table 2 shows the comparison of Tp-Te interval comparison before fibrinolysis, 0 minute, and 30 minutes after fibrinolysis in successful fibrinolysis group and failed fibrinolysis group.

In this study, Tp-Te interval evaluation was performed at 0 minutes (instantaneous) and 30 minutes after fibrinolysis. The Tp-Te interval value after successful fibrinolysis experienced significant reduction, both at 0 minute and at 30 minutes after fibrinolysis, $17.55 \pm 13.35 \mathrm{~ms}$ and $20.85 \pm 15.62 \mathrm{~ms}$ respectively. $\mathrm{Tp}-\mathrm{Te}$ interval reduction was not found in the failed fibrinolysis group, otherwise

Table1. Baseline characteristics based on fibrinolysis results in STEMI patients

\begin{tabular}{|c|c|c|c|}
\hline \multirow[b]{2}{*}{ Variables } & \multicolumn{2}{|c|}{$\begin{array}{l}\text { Fibrinolysis } \\
\end{array}$} & \multirow[b]{2}{*}{ P value } \\
\hline & Successful $(n=46)$ & $\begin{array}{l}\text { Failed } \\
(n=38)\end{array}$ & \\
\hline \multicolumn{4}{|l|}{ Gender, n(\%) } \\
\hline Male & $42(91.30 \%)$ & $35(92.11 \%)$ & 1.000 \\
\hline Female & $4(8.70 \%)$ & $3(7.89 \%)$ & \\
\hline Age in year (mean $\pm S D)$ & $56.11 \pm 9.907$ & $57.26 \pm 10.258$ & 0.602 \\
\hline Onset in hour (mean $\pm S D$ ) & $4.28 \pm 2.126$ & $4.45 \pm 2.190$ & 0.728 \\
\hline \multicolumn{4}{|l|}{ Infarct location, n(\%) } \\
\hline Anterior & $18(39.13 \%)$ & $30(78.95 \%)$ & $<0.001$ \\
\hline Non-anterior & $28(60.87 \%)$ & $8(21.05 \%)$ & \\
\hline \multicolumn{4}{|l|}{ Fibrinolytic agent, $\mathrm{n}(\%)$} \\
\hline Streptokinase & $35(76.09 \%)$ & $29(76.32 \%)$ & 1.000 \\
\hline Alteplase & $11(23.91 \%)$ & $9(23.68 \%)$ & \\
\hline Diabetes mellitus, $\mathrm{n}(\%)$ & $7(15.22 \%)$ & $9(23.68 \%)$ & 0.406 \\
\hline Hypertension, $\mathrm{n}(\%)$ & $25(54.35 \%)$ & $26(68.42 \%)$ & 1.000 \\
\hline Smoker, $\mathrm{n}(\%)$ & $36(78.26 \%)$ & $28(73.68 \%)$ & 0.797 \\
\hline Family history, n(\%) & $2(4.35 \%)$ & $1(2.63 \%)$ & 1.000 \\
\hline Hyperlipidemia, n(\%) & $9(19.57 \%)$ & $9(23.68 \%)$ & 0.790 \\
\hline
\end{tabular}

Note: $S D=$ standard deviation 
Table 2.Tp-Te interval comparison before fibrinolysis, 0 minute, and 30 minutes after fibrinolysis based on the success of fibrinolysis

\begin{tabular}{lccc}
\hline \multicolumn{1}{c}{ Variables } & $\begin{array}{c}\text { Successful fibrinolysis } \\
(\mathbf{n = 4 6 )}\end{array}$ & $\begin{array}{c}\text { Failed fibrinolysis } \\
(\mathbf{n}=\mathbf{3 8})\end{array}$ & P value* $^{*}$ \\
& & & \\
Before fibrinolysis, mean \pm SD & $120.30 \pm 13.02$ & $118.57 \pm 15.24$ & 0.576 \\
0 minute after fibrinolysis, mean \pm SD & $102.76 \pm 13.17$ & $119.34 \pm 16.38$ & $<0.001$ \\
30 minutes after fibrinolysis, mean \pm SD & $99.46 \pm 13.95$ & $120.11 \pm 20.43$ & $<0.001$ \\
\hline
\end{tabular}

*Unpaired T test, Tp-Te interval in units of milisecond (ms)

Tabel 3. Comparison of $\mathrm{Tp}-\mathrm{Te}$ interval changes $(\Delta T p-T e)$ based on the outcome of fibrinolysis

\begin{tabular}{lccc}
\hline & $\mathbf{n}$ & Mean \pm SD & P value* $^{*}$ \\
$\begin{array}{l}\Delta \text { Tp-Te before and } \mathbf{0} \text { minute after fibrinolysis } \\
\quad \text { Successful }\end{array}$ & 46 & $17.55 \pm 13.35$ & $<0.001$ \\
$\quad$ Failed & 38 & $-0.77 \pm 11.00$ & \\
$\begin{array}{l}\Delta \text { Tp-Te before and } 30 \text { minutes after fibrinolysis } \\
\quad \text { Successful }\end{array}$ & 46 & $20.85 \pm 15.62$ & $<0.001$ \\
$\quad$ Failed & 38 & $-1.53 \pm 14.35$ & \\
\hline
\end{tabular}

*Unpaired T test, Tp-Te interval in units of milisecond (ms)

there was little $\mathrm{Tp}$-Te interval prolongation, with the changes obtained was equal to -0.77 $\pm 11.00 \mathrm{~ms}$ at $0 \mathrm{~min}$ and $-1.53 \pm 14.35 \mathrm{~ms}$ at 30 minutes after fibrinolysis. Table 3 shows the comparison of $\mathrm{Tp}$ - $\mathrm{Te}$ interval changes $(\Delta \mathrm{Tp}-\mathrm{Te})$ based on the outcome of fibrinolysis.

The ROC curve showed that Tp-Te interval changes $(\triangle \mathrm{Tp}-\mathrm{Te})$ had a strong discriminator value with area under the curve (AUC) of 0.888. In this study, the cut-off value proposed as a parameter of successful fibrinolysis based on the ROC curve is $20 \mathrm{~ms}$. The value gave $52.2 \%$ sensitivity and $94.7 \%$ specificity, based on ROC curve analysis. Figure 2 and 3 showed the ROC analysis.

\section{DISCUSSION}

The baseline characteristics of the subjects of this study showed that the percentage of hypertension, diabetes mellitus, family history, hyperlipidemia, and smoking did not differ between the two groups. The risk factors of smoking was found in $78.26 \%$ of successful fibrinolysis group and as much as $73.68 \%$ in the failed fibrinolysis group. This number is very large, thus requiring special attention in cardiovascular disease prevention program. In addition, a high percentage of smokers subjects associated with increased mortality and arrhythmias. ${ }^{14}$

The mean onset of STEMI in each group was $4.28 \pm 2.126$ hours on the successful fibrinolysis group and $4.45 \pm 2.19$ hours in the failed fibrinolysis group. There are significant differences in infarct location of the two groups, in which the percentage of anterior infarct location in the failed fibrinolysis group more than the successful fibrinolysis. This corresponds with the results of previous studies by Lopeset al. ${ }^{16}$ that the anterior infarct location into one of the predictors of failed fibrinolysis. Nevertheless, infarct location does not affect the Tp-Te interval at baseline.

This study showed an increase in ventricular repolarization dispersion in acute phase of STEMI, assessed with intervals $\mathrm{Tp}-\mathrm{Te}$. There is no consensus regarding the normal value Tp-Te interval, but on the setting of myocardial infarction, value $\mathrm{Tp}-\mathrm{Te}$ interval of more than $100 \mathrm{~ms}$ are considered prolonged and associated with increased risk 


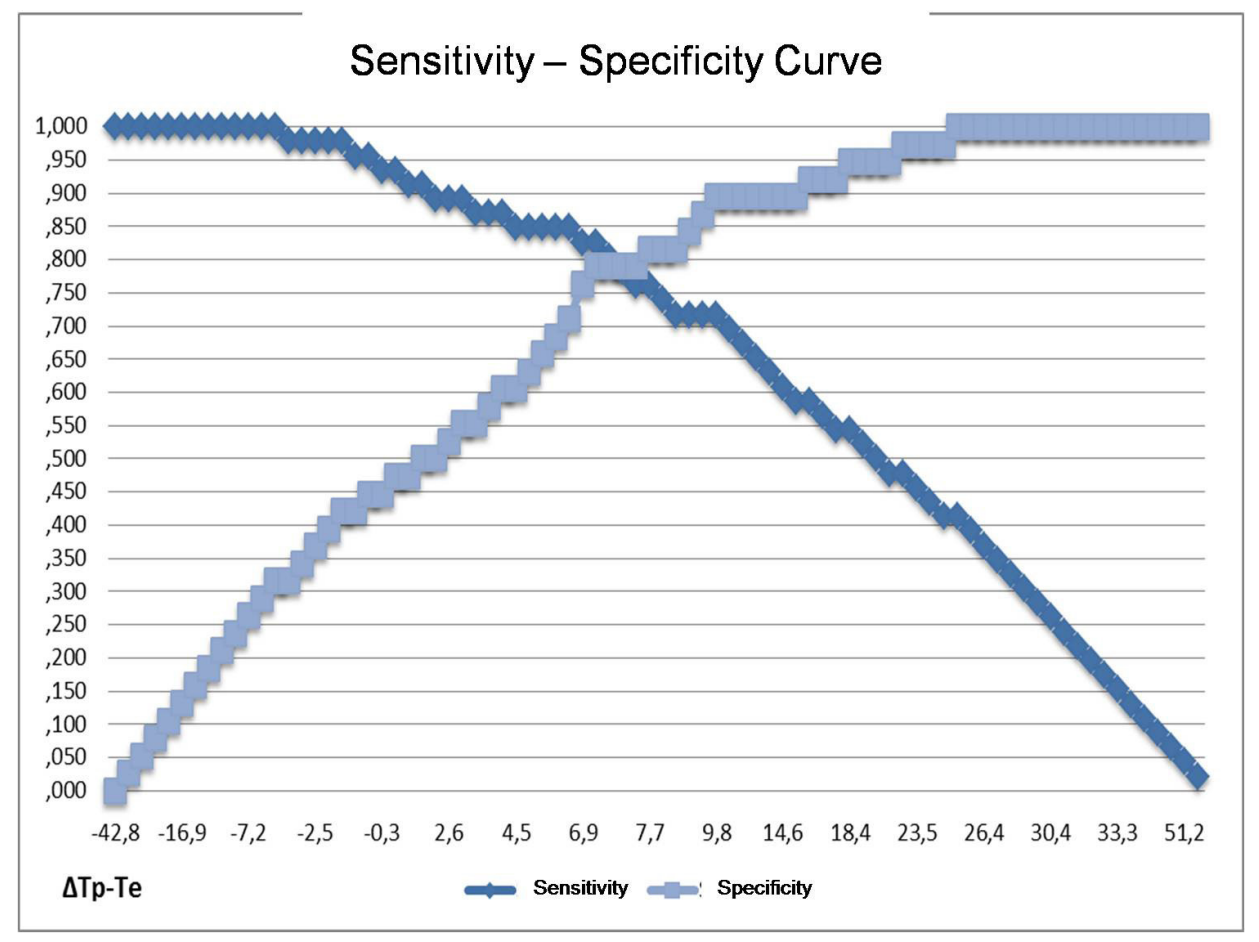

Figure 3. Sensitivity and specificity chart of $\Delta \mathrm{Tp}$-Te interval at 30 minutes after fibrinolysis

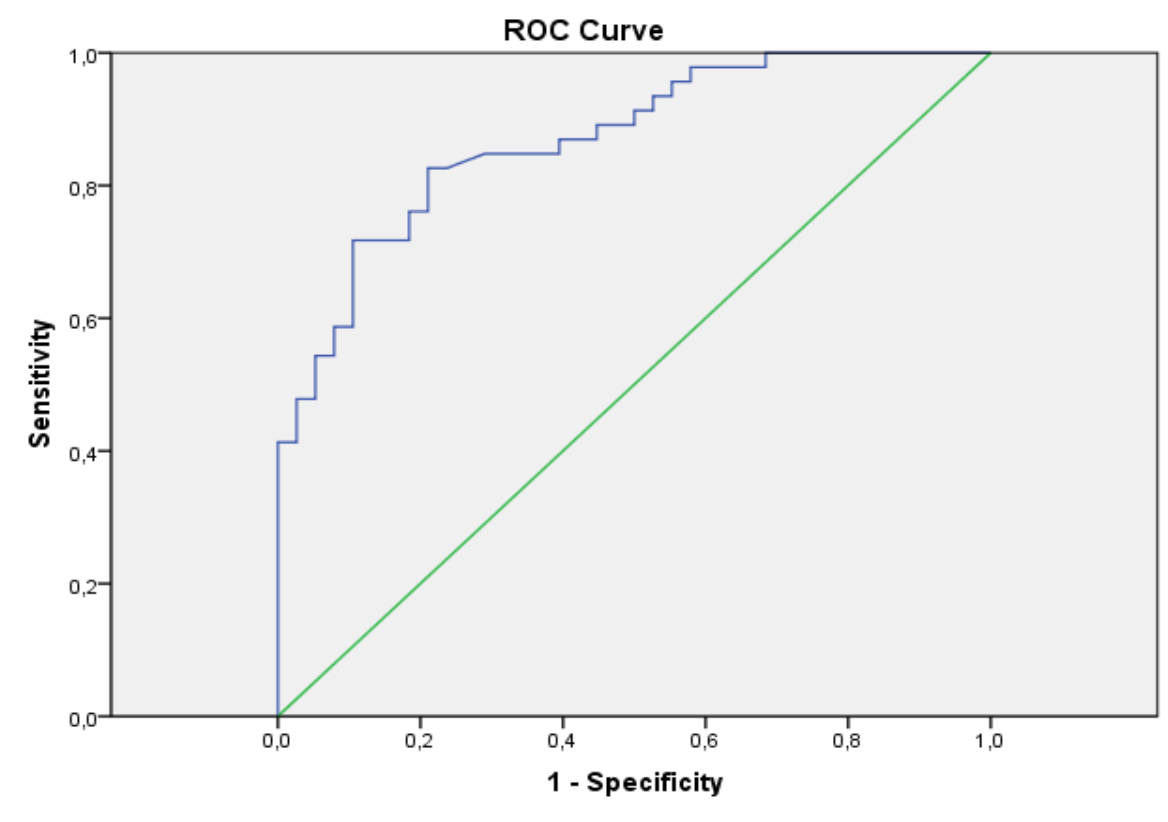

Diagonal segments are produced by ties.

Figure 2. The ROC of $\triangle T p-T e$ at 30 minutesto success of fibrinolysis 
of arrhythmias. ${ }^{13,17}$ In this study, obtained TpTe interval prolongation prior to the action of fibrinolysis in both groups of subjects, both in successful fibrinolysis group and failed fibrinolysis group, respectively $120.30 \pm 13.02$ $\mathrm{ms}$, and $118.57 \pm 15.24 \mathrm{~ms}$. This is according to a study conducted by Shentar et al. ${ }^{12}$ that compared normal individuals and STEMI patients, where there were lengthening of Tp-Te interval and Tp-Te/QT ratio in STEMI patients with a mean Tp-Te interval of $110 \mathrm{~ms}$ and the value of $\mathrm{Tp}-\mathrm{Te}>100 \mathrm{~ms}$ and the ratio $\mathrm{Tp}-\mathrm{Te} / \mathrm{QT}>0.3$ increases the risk of malignant ventricular arrhythmias in STEMI patients.

The main objective of fibrinolytic therapy in STEMI patients is achieving and maintaining coronary patency to improve left ventricular function and reduce mortality. Although the benefits of the use of fibrinolytic agents has been documented to reduce mortality in STEMI, the mechanism is still being debated, most likely through an improvement in the mechanical and electrical functions. ${ }^{18}$ Past studies by Lopes et al. ${ }^{16}$ showed that successful fibrinolysis reduced QT dispersion in STEMI patients. But until now there has not been studies evaluating the $\mathrm{Tp}-\mathrm{Te}$ interval before and after fibrinolysis.

This is consistent with research done by John et al. ${ }^{11}$ and Mahbubi ${ }^{19}$ in which there is a decrease $\mathrm{Tp}$-Te interval after reperfusion action, either by primary $\mathrm{PCl}$ or successful fibrinolysis. Moreno et al. ${ }^{18}$ demonstrated the beneficial effects of reperfusion in addition to the reduction of infarct size and improvement of myocardial function. In patients with a successful fibrinolysis outcome (TIMI 3 flow) shows more stable electrical substrate compared to persistent occlusion. Achievement of early patency correlates with reduced incidence of arrhythmias and cardiovascular death.

The same result was reported by Dey et al. $^{20}$ in which the decrease Tp-Te interval after reperfusion reduces the risk of ventricular arrhythmias, but it can not predict mortality within 30 days and heart failure.

Based on the ROC, it was found that $\triangle T p$ Te has a strong discriminator value with $A \cup C$ 0.888 . In this study, the cut-off valueproposed as a parameter of successful fibrinolysis is based on the ROC curve and the curve of the sensitivity-specificity, is the change interval Tp$\mathrm{Te}(\Delta \mathrm{Tp}-\mathrm{Te})$ of $20 \mathrm{~ms}$ with $52.2 \%$ sensitivity and $94.7 \%$ specificity. It is based on the consideration that the average $\Delta T p$-Te achieved on successful fibrinolysis group at 30 minutes after fibrinolysis revolves around these values. The limit value of $20 \mathrm{~ms}$ is also thought of as a value that can be observed more easily on the EKG. A span of 30 minutes after fibrinolysis is used as a reference in calculating $\Delta T p$-Te based on research by Vrachatis et al. ${ }^{21}$, in which the TIMI 3 flow on successful fibrinolysis achieved within 90-120 minutes after starting fibrinolysis. With this result, $\mathrm{Tp}$-Te interval can be an alternative parameter in assessing the success of fibrinolysis.

Limitations of this study is the ECG recording was not conducted prospectively, so less guarantee timely. The study also does not use angiographic parameters as the gold standard of the arterial flow patency resulting in less accurate in evaluating the diagnostic value of Tp-Te interval.

\section{CONCLUSION}

There was a greater reduction of TpTe interval in STEMI patients with successful fibrinolysis compared to failed fibrinolysis, so it may be used as a alternative parameter of successful fibrinolysis with sensitivity $52.2 \%$ and specificity $94.7 \%$.

\section{ACKNOWLEDGEMENT}

Authors thank dr. Erdiansyah Zulyadaini and dr. Mustika Mahbubi for their ideas, companion and assistance in some data collection during 
this study. This study was conducted with ethical clearance from the Ethical Committee of Faculty of Medicine Universitas Gadjah Mada.

\section{REFERENCES}

1. Widimsky P., Wijns W., Fajadet J., De Belder M., Knot J., Aaberge L., et al. 2010. Reperfusion therapy for ST elevation acute myocardial infarction in Europe: description of the current situation in 30 countries. Eur Heart J, 31: 943-57.

2. Burton F.L., Cobbe S.M. 2001. Dispersion of ventricular repolarization and refractory period. Cardiovasc Res, 50: 10-23.

3. Akar J.G., Akar F.G.. 2007. Regulation of ion channels and arrhythmias in the ischemic heart. J Electrocardiol, 40: S37-S41.

4. Carmeliet E. 1999. Cardiac ionic currents and acute ischemia: from channels to arrhythmias. Physiol Rev. 79: 917-1017.

5. Steg P.G., James S.K., Atar D., Badano L.P., Blomstrom-Lundqvist C., Borger M.A., et al. 2012. ESC Guidelines for the management of acute myocardial infarction in patients presenting with ST-segment elevation. Eur Heart J, 33: 2569-619.

6. Kalla K., Christ G., Karnik R., Malzer R., Norman G., Prachar H., et al. 2006. Implementation of guidelines improves the standard of care: the Viennese registry on reperfusion strategies in ST-elevation myocardial infarction (Vienna STEMI registry). Circulation, 113: 2398-405.

7. Sutton A., Campbell P., Grech E., Price D., Davies A., Hall J., et al. 2000. Failure of thrombolysis: experience with a policy of early angiography and rescue angioplasty for electrocardiographic evidence of failed thrombolysis. Heart,84 (2): 197-204.

8. Antzelevitch C., Shimizu W., Yan G.X., Sicouri S., Weissenburger J., Nesterenko V.V., et al. 1999. The M cell: its contribution to the ECG and to normal and abnormal electrical function of the heart. J Cardiovasc Electrophysiol, 10: 1124-52.

9. Jiang X., Zhao H., Ji Z., Liu G., Liu L. 2013. The Correlation of $T$ peak-T end Interval and ventricular arrhythmia in patients with acute myocardial infarction. Tianjin Med $\mathrm{J}$, 41: 740-743.

10. Hetland M., Haugaa K.H., Sarvari S.I., Erikssen G., Kongsgaard E., Edvardsen T. 2014. A novel ECG-index for prediction of ventricular arrhythmias in patients after myocardial infarction. Ann Noninvasive Electrocardiol, 19: 330-337.

11. John B., Dey S., Jacob J., Raghavan V. 2014. The prognostic value of $T$ peak - $T$ end interval on the surface ECG in patients undergoing reperfusion therapy for STEMI. Heart, Lung and Circulation, 23: e12.

12. Erikssen G., Liestol K., Gullestad L., Haugaa K.H., Bendz B., Amlie J.P. 2012. The terminal part of the QT interval (T peak to T end): a predictor of mortality afteracute myocardial infarction. Ann NoninvasiveElectrocardiol, 17: 85-94.

13. Shenthar J., Deora S., Rai M., NanjappaManjunath C. 2015. Prolonged Tpeak-end and Tpeak-end/QT ratio as predictors of malignant ventricular arrhythmias in the acute phase of ST-segment elevation myocardial infarction: a prospective casecontrol study. Heart Rhythm, 12: 484-9.

14. Abdelrahman T.M. 2014. Prognostic value of $T$ peak-to-end interval for risk stratification after acute myocardial infarction. The Egyptian Journal of Critical Care Medicine. 2: 19-27.

15. Eslami V., Safi M., Taherkhani M., Adibi A., Movahed M.R. 2013. Evaluation of QT, QT dispersion, and T-wave peak to end time changes after primary percutaneous coronary intervention in patients presenting with acute ST-elevation myocardial infarction. J Invasive Cardiol, 25: 232-234. 
16. Lopes N.H, Grupi C., Dina C.H., De Gois A.F., Hajjar L.A., Ayub B., et al. 2006. [QT interval dispersion analysis in acute myocardial infarction patients: coronary reperfusion effect]. Arq Bras Cardiol. 87: 91-8.

17. Haarmark C., Hansen P.R., Vedel-Larsen E., Pedersen S.H., Graff C., Andersen E.,et al.2009. The prognostic value of the TpeakTend interval in patients undergoing primary percutaneous coronary intervention for STsegment elevation myocardial infarction. J Electrocardiol, 42: 555-560.

18. Moreno F.L., Villanueva T., Karagounis L.A., Anderson J.L. 1994. Reduction in QT interval dispersion by successful thrombolytic therapy in acute myocardial infarction: TEAM-2 Study Investigators. Circulation, 90: 94-100.

19. Mahbubi M. 2016. [Pengaruh Jenis Reperfusi terhadap Perubahan Interval Tpeak-Tend pada Pasien Infark Miokard Akut dengan Elevasi Segmen ST]. Thesis. Universitas Gadjah Mada.

20. Dey S., Jose J., George P. 2016. The Effect of reperfusion on repolarization index ( $T$ peak - $T$ end interval) on the surface Electrocardiogram in patients with STsegment Elevation Myocardial Infarction and its prognostic significance. Indian J Applied Res, 6: 99.

21. Vrachatis A.D, Alpert M.A., Georgulas V.P., Nikas D.J., Petropoulou E.N., Lazaros G.I., et al. 2001. Comparative efficacy of primary angioplasty with stent implantation and thrombolysis in restoring basal coronary artery flow in acute ST segment elevation myocardial infarction: quantitative assessment using the corrected TIMI frame count. Angiology, 52: 161-166. 